\title{
M Protein
}

National Cancer Institute

\section{Source}

National Cancer Institute. M Protein. NCI Thesaurus. Code C17788.

A protein complex comprised of two heavy chains and two light chains. Monoclonal immunog lobulin (M protein) is found in abundance in patients who have multiple myeloma. The protein is not produced in response to an antigen, but it is expressed in malignant plasma cells and excreted into the blood and urine. 